\title{
Authorship and Originality in Seventeenth-Century Iberia: Faria e Sousa's Rimas Várias de Luís de Camoens
}

\author{
Simon Park
}

\begin{abstract}
\end{abstract}
Manuel de Faria e Sousa's Rimas Varias de Luis de Camoens (1685-8) continues to be the most influential edition of and scholarly work on Camões's lyric oeuvre. While his attributions have been widely debated (and many disproved), the reasons Faria e Sousa puts forward for them have received only cursory attention. The commentator's strikingly psychological explanations for ascribing texts to Camões suggest unexpected ways in which lyric authorship could be conceptualized in the seventeenth century. How he deals with the proliferation of texts in manuscript miscellanies illuminates where the line lay between variants, poorly-concealed plagiarism, and entirely new poems. In other words, what makes a poem original. Faria e Sousa's edition points to a prehistory of claims to author's rights and authorial originality before the introduction of copyright legislation and highlights the role that editors played in the construction of modern authorship, suggesting they might be as possessive of texts, if not more so, than writers themselves.

In his edition of Luís de Camões’s (c.1525-80) lyric poetry, Manuel de Faria e Sousa (1590-1649) boasts of adding two hundred poems to the Camonian corpus. ${ }^{1}$ Scholars have been responding anxiously to his editorial actions ever since. ${ }^{2}$ Talk of attributions prompts such unease because the name we associate with a given text influences our evaluation of its merits as well as our assessment of the writer's work as a whole. Stripping a poem of a name completely is, to some critics, like condemning it to a fate worse than death. Vítor de Aguiar e Silva, for instance, laments that muchadmired poems, once claimed to be by Camões, but de-attributed by Brazilian editors, Leodegário de 
Azevedo Filho and Emmanuel Pereira Filho, now float 'numa espécie de limbo,3 [in a kind of limbo] - a turn of phrase that makes plain the salvation he thinks comes from a text's association with a name, particularly if that name is Camões's.

Given what is at stake — the reputation of Portugal's most-prized author—much has been written about the plausibility of Faria e Sousa's additions to Camões's oeuvre. Editors usually present their own criteria to assess the attribution of poems, skipping over the case Faria e Sousa himself advances, and, despite some detailed studies of the eclogues, critics rarely comment on the process by which Faria e Sousa makes his attribution beyond mentioning in passing the circular connections he draws between biography and poetry. ${ }^{4}$ Yet, Faria e Sousa sets out some surprising grounds for his claims, grounds that manifest continuities between modern and early modern ideas about authorship and originality and can change our perception of how it was possible to conceive of authorship in the seventeenth century. ${ }^{5}$ Rather than relying on style, which Kathy Eden has identified as central to proprietary claims of authorship in the early modern period, ${ }^{6}$ Faria e Sousa argues for his attributions and dismissal of variants with recourse to notions of originality that tend to be associated with the rise of intellectual property legislation in the eighteenth century. He distinguishes variants not only on the basis of wording, common in earlier editions of Camões's work, but using ideas of conceit, structure, and intention to judge a poem's authorship.

In his discussion of attributions, Faria e Sousa puzzles over what counts as 'his' or is 'proper to/for' a given author, suggesting, in a surprising editorial move, that poems written at the behest of others do not truly belong to the poet himself, thereby shifting the terms on which a text can be connected to a proper name and what effect this might have. In claiming authorship on someone else's behalf, Faria e Sousa's edition demonstrates through its bold and combative rhetoric that affixing a name to a text can often matter less to writers themselves than to everyone else. ${ }^{7}$

Faria e Sousa's first editorial project was a monumental edition and commentary of Camões's epic poem, Os Lusíadas, printed in Madrid in 1639. He only turned his attention to the lyric in the 1640s, he tells us, in response to claims in Spain that Camões was at his best in his 'Poemas varios' [various 
poems]. Faria e Sousa dismisses claims that his lyric work could equal his epic masterpiece-it belonged to a lesser sphere (i, 'Prologo' §5)—but praises its excellence on its own terms. For him, Camões was remarkable because he excelled across poetic genres: 'España solamente en Luis de Camões vió juntas las glorias de Homero, Virgilio, Pindaro, Horacio, Plauto, y cada uno de essotros ya referidos' (i, 'Juizio' §2) [Only in Luís de Camões did Spain see the glories of Homer, Virgil, Pindar, Horace, Plautus, and every other author already mentioned joined together]. This hyperbole echoes many other texts of the period that sought to trumpet Portuguese cultural superiority, first during the turbulent years leading to Portugal's regaining independence from Spain in 1640 and then in the early years of the Restoration, which were marked by a renewed national pride. ${ }^{8}$ As Faria e Sousa insists, commentary was a genre reserved for the most prestigious authors, so annotating Camões's work, and doing so in Castilian, a language with a broader European reach than Portuguese, was evidently a move to elevate Camões to the highest echelons of European poetry (i, 'Prologo' §6). ${ }^{9}$ His editorial project shared one of the key ambitions of early book production, namely, 'transforming manuscripts into Great Works, and identifying individuals, on the basis of these works, as esteemed and independent Authors'. ${ }^{10}$ Although clearly intended for the printing press, the first volume of the Rimas varias only appeared in type in 1685, some 36 years after Faria e Sousa's death, the second three years later in 1688 , and comments from the remaining volumes took almost another century to appear in print, being included only in Tomás José de Aquino's 1779-80 edition of Camões's complete works.

Editing Camões's lyric poetry presented problems of authorship that Faria e Sousa had not faced when working on Os Lusíadas. Lyric circulated mostly in manuscript miscellanies in the sixteenth century, usually anonymously, sometimes with different attributions in different manuscripts, and frequently subject to the additions, alterations, and annotations of scribes and readers. ${ }^{11}$ Consequently, the number of poems attributed to Camões fluctuated with each printed edition of his lyric for the first half century after their typographical début in 1595, as editors discovered anonymous poems and claimed them for Camões or tore the labels from poems previously tagged with his name in light of new evidence. Indeed, editors and printers consistently advertised 
their editions as newly corrected and expanded on their frontispieces as if they needed to keep revisiting attributions so they could successfully market their books. ${ }^{12}$

This competition may have been one motivating factor in Faria e Sousa's dramatic expansion of Camões's corpus. More important, and underlying this market competition, was his explicit editorial desire to establish Camões as Portugal's Prince of Poets. To do so involved, as with many vernacular authors in the early modern period, the creation of a book that bound together all Camões's texts. ${ }^{13}$ However, Faria e Sousa did not just seek to make Camões a Great Author. He wanted to make him the only Great Author in Portugal. He argued that all good poetry produced in the sixteenth century came from Camões's pen, because all other writers of verse at the time were mere versificadores incapable of the conceptual or formal sophistication of a true poeta: 'todos los todos los Portugueses que entonces imprimian, y tratavan de imprimir lo que escrivian, como Francisco de Sá y Miranda, António Ferreyra, y Geronimo Corte Real [...] eran unos meros versificadores desnudos de quanto es Poesia' (i, ‘Juizio’ §20) [all the Portuguese who printed or set about printing what they wrote, such as Francisco de Sá de Miranda, António Ferreira, and Jerónimo Corte-Real [...] were mere versifiers lacking what Poetry consists of]. Faria e Sousa leads us to believe that a much larger number of poems belonged to Camões than had previously been thought. Lesser writers had taken advantage of the fact that Camões died before them to pilfer his poems and pass them off as their own in books produced towards the end of the sixteenth century. Faria e Sousa thus systematically scooped up any poems he thought were of quality either in manuscripts or in printed books and collected them under Camões's name. In doing so, he pushed the notion of the author as, in Foucault's words, a 'principle of a certain unity of writing' to its limits. ${ }^{14}$ In Foucault's discussion of St Jerome, consistent quality across an oeuvre becomes a rationale for ejecting texts of a perceived lower standard from a writer's oeuvre, thereby maintaining authorial coherence and integrity. For Faria e Sousa, it works in the opposite direction with greater scope: the premise that Camões was a great writer legitimizes Faria e Sousa's unprecedented expansion of his oeuvre, absorbing all 'good' poetry dated from his lifetime (and sometimes even after it, if Faria e Sousa thought it was a variant of one of Camões's poems). ${ }^{15}$ To adapt one of his own metaphors, the vision Faria e Sousa offers of the sixteenth century is one of a 
single poetic star shining against a shadowy backdrop of lesser versifiers (i, 'Prologo' §6). And he is the astronomer plotting this constellation.

A particular target of Faria e Sousa's mass reattribution was Diogo Bernardes. In the story Faria e Sousa tells about the sixteenth century, Bernardes was a villain who nefariously purloined Camões's poetry after his death (and, to Faria e Sousa's mind, failed to cover his tracks very well). As he says in an oft-cited passage from the 'Juizio destas Rimas' ['Appraisal of these poems'], 'ay muchas cosas que èl [i.e. Bernardes] usurpó a Luis de Camões, y las más della van agoras en esta Edicion, porque tuve por justo restituirle, destos robos' (i, 'Juizo' §20, punctuation altered) [there are many things that Bernardes usurped from Luís de Camões, and most of them are now included in this edition, because I thought it was just to recompense him for these thefts]. While critics regularly cite this quotation as a sign of Faria e Sousa's hostility to Bernardes, it also shows how he conceptualizes authorship and presents the role of the editor. To call Bernardes's alleged actions 'theft' conceptually aligns authorship with ownership, at least to the extent that it suggests a writer had a moral right to have their name associated with the texts that they wrote. Couching this act of fraudulent attribution in such legal terms is surprising insofar as the law at the time did not afford writers such protections. Royal privileges gave guarantees primarily against piracy, not plagiarism. Moreover, privileges were usually granted to booksellers, financiers, or printers, rather than to writers, and they did not extend to what Faria e Sousa discusses here, namely, passing off individual texts as one's own within a larger book of poetry. ${ }^{16}$

To look at it from a slightly different angle, the law set a low bar for originality—a book counted as new, and thus not a pirate, as long as it was not an exact copy. ${ }^{17}$ As we will see, Faria e Sousa set a much higher 'threshold' for originality. Simon Stern has discussed the differing thresholds for originality, and his analysis informs mine, although he wrongly characterizes the period before 1670 as largely uninterested in questions of attribution, plagiarism, and textual accuracy, which was plainly not the case. ${ }^{18}$ Indeed, Faria e Sousa makes clear that minor differences in wording were not enough to make two texts count as fundamentally different poems, which meant, for him, that they could not be ascribed to different authors. His legalistic language both posits Camões as the rightful 
'owner' of his works, and casts himself as the just arbiter who offers posthumous restitution. Much as in his other works, Faria e Sousa wastes no time in signaling his own virtues. ${ }^{19}$

Faria e Sousa's reactions to Bernardes's work are curious because they change in intensity depending on the context in which they appear. In his edition of Os Lusíadas, he is barely interested in Bernardes, because he is someone who never attempted an epic poem. ${ }^{20}$ More positively, in his Fuente de Aganipe (1644), Faria e Sousa cites Bernardes as a good example of a bucolic writer in the poem 'Pan i Apolo'. ${ }^{21}$ He mentions his doubts about the authorship of some of the eclogues in the 'Prologo' to the fourth part of this work, ${ }^{22}$ but adopts a measured tone, different from that which he would eventually take in his introduction to Camões's ninth eclogue in his Rimas Varias, where he again states that Bernardes was entirely incapable of producing good poetry and that therefore these eclogues must be by Camões. ${ }^{23}$ When Faria e Sousa sees Bernardes as a threat to Camões, he rails against him in vituperative terms. Indeed, Bernardes's eclogues were usually seen as the best of his work and might challenge Camões's in terms of quality. ${ }^{24}$ Moreover, the need to dismiss Bernardes intensified when he came to edit Camões's work, where the question of authorship was much more fundamental to his undertaking. His criticism of Bernardes only relents in the Rimas when he discusses the sonnet Bernardes wrote in praise of Camões for the first edition of the Rhythmas from 1595. It is, for Faria e Sousa, 'el mâs limpio, aunque no sea muy bueno' [themost limpid, even if it is not very good] ('Juizio’ §20). Evidently, he would not want to re-attribute this poem, as it provides sixteenth-century evidence to corroborate his own view that Camões was a poet beyond comparison. The sonnet poses no threat by its attribution and, consequently, Faria e Sousa does not need to be quite so aggressively critical of it.

Manuscript circulation made life difficult for Faria e Sousa in his quest to be the righteous redresser of poetic misappropriations, as similar texts were often attributed to different names. As Mark Rose points out, 'copyright depends on drawing lines between works, on saying where one texts ends and another begins', although the same issue applies much before copyright in any attempt to establish attributions. ${ }^{25}$ The sticking point for Faria e Sousa was proving that the 'difference' between two texts was not enough to count them as individual poems, but rather, to use the language of 
modern editing, that they should be deemed variants. He weighs this question when discussing the sonnet 'Depoys de tantos dias mal gastados' ['After so many ill-spent days']:

En las Rimas de Bernardez es 77. Este Soneto, de que nadie ja màs dudó que era de Luis de Camões, como realmente es, aun que con alguna diferencia: y esto, ò porque él no alcançó los originales más limados, ò porque los quiso disfrazar cõ alteraciones: ignorando que se estos robos se pueden encubrir a algunas vistas, a otras es impossible: y aunque la mia no sea de las mas agudas, yo le he cogido en los muchos que voy manifestando, porque se dé a Cesar lo de Cesar, y para que cada uno entienda que el tiempo lo descubre todo. (i, 117)

[This is number 77 in Bernardes's Rimas. This sonnet, I never doubted was one of Camões's, as it really is, despite some differences: and these exist either because Bernardes could not get his hands on the more polished originals, or because he wanted to disguise them with alterations, forgetting that if these thefts can be hidden from some eyes, from others it is impossible. And even though mine may not be the sharpest, I spotted it in the many instances that I indicate here, because one renders to Caesar that which is Caesar's, and I do this so that everyone realizes that time reveals all.]

Even though there are some discrepancies between the text he cites in his edition and the one printed in Rimas várias flores do Lima (1597), Faria e Sousa concludes that they are not fundamentally different texts. ${ }^{26} \mathrm{He}$ explains the differences away by Bernardes's lack of access to 'los originales más limados' [the more polished originals ] or, more cynically, by imputing to Bernardes a desire to pass the poem off as his own with just a few minor alterations made to conceal the crime. The allusion to Mark 12:17 ('render unto Caesar that which is Caesar's'), in the light of this accusation, reiterates the rhetoric of the edition as a whole, that each should get their due. It is not right for Bernardes's name to be associated with this text, even in its variant form, because it really belongs to Camões. Faria e Sousa warns his readers against attempting anything similar themselves by invoking the commonplace, tempus omnia revelat: if they try to pass others' work off as their own they will eventually be caught, just as he says he apprehended Bernardes here.

The mise-en-page of the printed edition of the Rimas varias reflects Faria e Sousa's inclination to subsume multiple texts to one master text. The typographical arrangement of the pages 
tames the shape-shifting tendencies of manuscript, offering readers a single, fixed form for each poem, catalogued with an identifying number. His comments, like those cited above, figure in smaller type, and what we might call textual relatives - poems that Faria e Sousa classes as early drafts, corrupted copies, or verses from elsewhere in Camões's oeuvre that bear formal or thematic resemblance to the text in question - appear in italics to contrast with the roman type of the canonized poem.

Reaching a decision about which poem to canonize, or, more broadly, setting the boundaries of where one writer's work started and another's ended was complicated in the early modern period., not just for, to use Zumthor's word, the mouvance of manuscript circulation, but due to the essential and enthusiastic intertextuality at the heart of the writing process. ${ }^{27}$ Imitation meant that early modern writers always entered into dialogue with other writers, be they ancient or contemporary. Indeed, although coeval imitation does not receive the same degree of scholarly attention, it was a no less integral part of poetic creation in the sixteenth century, making the issue of manuscript variants all the more fraught. Pêro de Andrade Caminha, for example, said of António Ferreira that imitating him was as good as imitating the ancients. ${ }^{28}$ However, as Thomas Greene points out, there was a difference between slavish imitation, paralyzed by reverence, and creative imitation that enacted a 'loving sacrilege' on the source text. ${ }^{29}$

The line between legitimate borrowing and transgressive appropriation was thin and mobile. Writers in the early modern period were quick to criticize those who copied too closely, usurped, or plagiarized others' writings, even though what would be praised in one author would quite often be condemned in another. ${ }^{30}$ If for a long time scholars posited the emergence of copyright legislation in the eighteenth century as a radical turning point in the history of authorship, recent scholarly interventions have shown that the journey towards modern authorial autonomy and claims to ownership of texts has many loops and detours. ${ }^{31}$ Kathy Eden, for instance, has persuasively shown that ancient and early modern authors invested in style as the basis of their individuality as authors and of a moral, if not legal, proprietary claim to their writing. ${ }^{32}$ Faria e Sousa's edition adds grist to Eden's revisions of the history of authorship in that he also claims that poems are Camões's on the 
basis of their style. More surprisingly, he also asserts authorship on the basis of ideas, which were often thought in the early modern period to belong to the public domain. ${ }^{33}$

Faria e Sousa tended to dismiss discrepancies between texts at the level of wording as unimportant, subsuming such variations to a single, master text in his edition. Earlier editors of Camões's work, however, argued that these lexico-syntactic variations were significant and printed what Faria e Sousa would consider 'variants' as separate 'main' texts, thereby suggesting how far editorial rationales were in flux. One example is 'Mandame Amor que canta o $\tilde{q}$ alma sente' ['Love orders me to sing what the soul feels'] from the 1616 Segunda parte [Second Part], where the introductory rubric states: 'Esta Canção duas vezes fez o Author com os mesmos conceitos, mas termos taõ differentes que totalmente he outra, hũa se imprimio q̃ começa, Mandame Amor q̃ cante docemente, esta he tão boa, que não se deixa ver qual he a que elle aceitou, \& assi ambas saõ merecedoras de se imprimir' [The author wrote this poem twice with the same conceits, but with such different terms that they are completely different; one was printed that begins 'Love orders me to sing sweetly', [but] this one is so good that it is not possible to tell which is the one the author preferred, and so both are worthy of being printed]. ${ }^{34}$ The editor draws a distinction between 'conceitos' and 'termos.' Whilst the conceit might be the same in both this text and the one printed earlier, the wording ('termos'), he argues, makes it a different poem. Despite saying the poem 'totalemente he outra' the edition indicates that various stanzas remain the same as those that figured in the earlier printed version ('Este ramo està quasi todo na que está impresso' [This section is almost entirely the same as the one already in print] $).{ }^{35}$ By his measure, two stanzas can make a poem of seven 'completely different,' which, to recall Simon Stern's words again, indicates that a relatively low threshold for originality (i.e. novelty) operates. In this example, the editor is not ascribing different proper names to these texts (they are both by Camões), but this rubric is nonetheless illuminating because so much of the discussion in Faria e Sousa's edition around attribution concerns how far and in what ways a text has to be different to allow a different claim to authorship. A comparison with the editorial protocol of the Segunda parte also shows that while in one respect Faria e Sousa sought to enlarge Camões's oeuvre, in others he restricted its proliferation by subsuming several variants to a single, master text. 
In the example of 'Depoys de tantos dias mal gastados' the differences were relatively few, but on occasion they could be quite significant. Such instances are where Faria e Sousa operates with a more abstract notion of what makes a poem distinct or original. For example, when dealing with another sonnet that appears in Bernardes's oeuvre, Faria e Sousa comments:

En las Rimas de Bernardez [...] anda otro Soneto a este mismo assunto, y con semejante jugete: y tenho por infalible que era de mi P. porque tiene el mismo exordio, y pensamiento; pero mejoróle aqui; y era costumbre muy suya el hazer un Poema dòs y tres vezes. (i, 40) [In Bernardes's Rimas, there is another sonnet on the same subject, with a similar game and I think it is undoubtedly by my poet because it has the same opening and ideas, but Camões improved it here: it was his particular wont to redo a poem two or three times]

The 'assunto,' 'jugete,' 'exordio,' 'pensamiento' enable him to establish a link between the two texts. In terms of rhetorical divisions, he locates the link between the poems in those parts of composition called inventio and dispositio, ignoring those differences at the level of elocutio that Kathy Eden suggests tended to offer the most opportunity for claims to 'ownness' or ownership in the early modern period. In this way, Faria e Sousa seems to anticipate much later debates around intellectual property, based around the complex notion that ideas can be patented. ${ }^{36}$

'Differencia' in wording, the essential problem for his attribution, is overlooked in favor of parallels at the level of conceit. In other words, a poem's originality or uniqueness resides partially in its 'assunto,' 'jugete,' 'exordio,' and 'pensamiento,' not only in its style. Discrepancies in the latter can be explained away with a narrative of revision and improvement. Curiously, Faria e Sousa claims that Camões was particularly wont to rewrite his poems two or three times, which seems a slight against other, less diligent poets and a convenient explanation for the many variants that he uncovers. It is also quite untrue that this was a 'costume muy suya,' given how seriously Horace's injunction to polish and file poems was taken by most of Camões's contemporaries. ${ }^{37}$

In other places in his edition, Faria e Sousa is subtler in his mode of engagement with the reader, using reflexive structures that offer no subject of the verb to quarrel with ('no se puede negar' (i, 314) [it cannot be denied]). It is harder to disagree with him if he does not make attribution a matter of his own opinion. He even has the poem itself declaring who wrote it in a bid to persuade his 
readers of his attribution: 'escusaré ya de mostrar con razones este robo, porque ademas de constar de los Originales, el Soneto con su limpieza, y felicidad està deziendo cuyo es' (i, 205) [I will dispense with giving reasons for identifying this as a theft, because besides being among the originals, the sonnet declares whose it is with its clarity and felicity]. He does not want readers questioning his judgement, so leaves it up to the reader who is encouraged to observe the (apparently) obvious.

Although his desire seems to have been to attribute as much as possible to Camões, Faria e Sousa was conscious that overattributing might have negative consequences:

Yo doy todo lo que he hallado con sombra de suyo; porque de semejantes hombres todo es venerable. Pero no he querido tambien molestarle con poner por suyo lo que no lo es, como se hizo en la segunda Parte, poniendo en su nombre lo que dixe alfin del Prologo. Basta que le molestemos con poner lo que el no aprovô por suyo aunque lo escriviesse. (i, ‘Juizio’ §11) [I give here everything that I have found that has the appearance of being his, because of such men everything is praiseworthy. But I did not want him to take offense by including what is not his own, as happened when the Second Part of his lyrics was printed and what was said at the end of the Prologue was put in his name. It's enough that we offend him by classing what he had not approved as his, even though he might have written it.]

The keyword to understanding Faria e Sousa is the possessive pronoun 'suyo': what counts as his? This question appears to have two different answers. The rationale of the editor is maximal attribution. He attributes to his author 'todo lo que he hallado con sombra de suyo.' In contrast, as Max Thomas notes, the author's attitude is often one of greater selectivity: he disowns some of the products of his pen and calls only his best creations 'his. ${ }^{38}$

At this point in his 'Juizio destas Rimas,' Faria e Sousa is dialoguing with a paratext from an earlier edition: the 'Prologo aos lectores' ['Prologue to readers'] from the first printed edition of Camões's Rhythmas (1595). Faria e Sousa opens this section of the 'Juzio' with a translated quotation from this earlier prologue, as he does in many sections of the 'Juzio': 'es injusto publicarse por de un Poeta famoso algunos Poemas que el no reconoce por suyos, aunque los hizo; porque haziendose a 
instancia de amigos, ó personas de respeto se hazen con prisa, y sin cuydado; y tales escritos no son suyos, sino de quien los pidió con aquella prisa' (i, 'Juizio' §11; original italics) [it is unjust to publish certain Poems as being by a famous Poet when he does not recognise them as his own, even though he wrote them; because writing them at the behest of friends, or important people, they were written in a hurry, and without care; and such writings are not his own, but belong to those who requested them with such haste]. The second half of this quotation introduces a surprising modification of what can count as 'suyo.' Texts written at another's behest are not the author's, but the requester's. Faria e Sousa explains further:

no se ha de llamar propio de un Poeta lo que el escrive incitado de voluntad agena: lo de la propia es solamente propio: y particularmente en la materia amorosa; porque es necessario que uno estè enamorado del sugeto a que escrive, para acertar, y no lo puede hazer suno lo està, como no lo puede estar de la Dama que el no enamora. (i, 'Juizio’ §11) [it shan't be called a Poet's own work that which he writes at the suggestion of another's will: what is his is only his: and particularly when it comes to matters of love; because it is necessary that one be in love with the subject to whom one writes, in order to be correct, and one cannot do so unless one is enamoured, just as one cannot be enamoured with the Lady that doesn't inspire love]

In his own account, the operative word is no longer 'suyo' but 'propio', which Covarrubias defines as 'lo que es de cada vno' [that which belongs to each individual] in his dictionary. ${ }^{39}$ Both words appear as keywords of the attribution process in many of the examples already cited and both are words whose Latin roots were long used to articulate a sense of authorial ownership, as in Petrarch's suggestion that writers could cultivate an 'individual and personal' (suum ac proprium) style. ${ }^{40}$ Faria e Sousa says that a poem written on command cannot be considered 'propio' because the spur for its creation was the 'voluntad' of another person. The circumstances of composition can loosen the knot between a writer's name and a poem. Possession of a poem depends on whose idea it was to write it first. Considering how much the prospect of patronage motivated writing in the early modern period, and the very social circumstances in which poets composed verse, it is a striking claim, one which raises a fundamental question about where patronage poetry sits within a writer's oeuvre and about 
the perceived intentionality of verse. Shades of Faria e Sousa's reservation linger in criticism today, where occasional verse receives short shrift. If we were to construct many early modern writers' oeuvres based on those texts most frequently discussed, patronage poetry would likely drop from their complete works.

More extraordinary is Faria e Sousa's claim that love poetry is a kind of writing where the 'propio,' the unique and personal, is most necessary. He says that you cannot write love poetry without being in love — readers are forgiven for thinking we are dealing with a nineteenth-century edition here. This brings a new factor into play in debates around writers' rights to make proprietary claims to their works: genre. Since love poetry is the privileged province of the 'propio,' it follows that it might be the genre that allows for the strongest claims to ownership. He demonstrates that different kinds of writing imply different conceptions of authorship. Or, to put it in more directly Foucauldian terms, that the 'author-function' influences different discourses in specific ways at different points in time. For Faria e Sousa, love lyric demands a named author and encodes biographical clues - what Foucault calls 'shifters' - that enable the identification of an author in cases of doubt. ${ }^{41}$ Love poetry needs an author because it is seen as the intentional record of an individual's experience of desire. As much as love poetry is nourished by intertextuality—Faria e Sousa diligently identifies such connections in his commentary— he sees it as fundamentally based on the writer's life. This is surprising given that the extensive manuscript circulation of poetry often did not indicate authorship for love poetry, as though biography or personal circumstances of composition were not essential to the understanding and enjoyment of this poetry in this mode of circulation.

Faria e Sousa's suggestion is not without precedent. We find a similar distinction in the Spanish Humanist, Juan Luis Vives's On Education where he suggests that while orators and poets might both be said to give birth to their works, the philosopher can only be said to have found truth that is already out in the world. ${ }^{42}$ Anticipating the Romantics, Vives and Faria e Sousa locate the origin of poetry in the experience of the writer and that its truths are personal not universal.

How far does Faria e Sousa take these suggestions in the practical task of attribution? Let us consider two examples from his commentary on the sonnets. 
The first 'As horas breves do meu contentamento' ['The fleeting hours of my happiness'] is a sonnet with multiple attributions in manuscripts. The problem of variants arises again as, according to Faria e Sousa, the tercets in the version included in Rimas Várias Flores do Lima differ greatly ('En Bernardez tienen alguna differencia los quarteles; y mucha los tercetos' (i, 289) [In Bernardes there is some difference in the quatrains and much in the tercets. Once more he suggests 'estilo' [style] and 'assunto' [subject-matter] as two of the potential axes on which difference between poems might be measured, explaining away stylistic variations again as a result of Bernardes's failure to acquire the 'improved' version of the poem. But Faria e Sousa adds to the question of 'assunto' that both poems must be by Camões because they describe the fate that he suffered ('fue propia suya la fortuna en el referida' [it was his particular fortune in the matter referred to]). He goes on to say later in the commentary on this poem that despite being attributed to Francisco de Sá de Miranda in some manuscripts too, it was definitely not by him because he 'casó por contrato, y no por amores, con una Señora de mucha edad' (i, 290) [had an arranged married, and did not marry for love, with a very old lady]. As Faria e Sousa said in his 'Juizio,' you cannot write a love poem if you are not in love.

A second poem that illustrates, in a different manner, Faria e Sousa's view of poetic creation, which then feeds into his strategies of attribution, is a sonnet printed in the first edition of Diogo Bernardes's Rimas Várias Flores do Lima: 'Brandas agoas do Tejo, que passando' ['Gentle waters of the Tagus, that passing...']. Faria e Sousa comments: 'Este Soneto escribiò el P. al tiempo que en Lisboa andava de partida para la India; mas no sabrè dezir si fue el año 1550. En que estuvo alistado para partir, y no partio; si el de [1]553. En que alfin ubo de partir. Fue Diego Bernardez tan insolente usurpador de los Escritos deste hombre, que sin reparar en lo que ellos dezian impropio de los sucessos de su vida los publicó por suyos' (i, 203) [the poet wrote this sonnet during the time when he was about to embark for India, but I do not know whether this was in 1550 , when he was ready to leave, but did not, or in 1553 when he eventually did depart. Diogo Bernardes was such an insolent usurper of the writing of this man that without thinking about the fact that they narrate things that did not apply to his life, published them as his own]. Faria e Sousa then enumerates three reasons as to why this is 'improprio': 1) Bernardes could never have spoken in this way; 2) he only ever pined for the Lima, never for the Tagus; and 3) he never suffered the kind of absence that this poem anticipates. 
The first reason depends on Faria e Sousa's characterization of Bernardes as a versifier and his appreciation of the sonnet's quality. The second has some basis in the fact that Bernardes did fashion himself as the poet of the Lima, rather than the Tagus, but this sonnet forms part of a sequence of three poems that narrate a journey from Lisbon to the Lima, passing by the Mondego. This suggests that Faria e Sousa deals with attribution on the basis of individual poems, rather than considering poems in sequence. The third reason is the most intriguing as it involves a judgement of the intensity of the emotions expressed in the poem and an evaluation of the circumstances in which Bernardes or Camões could have written it. Bernardes, he concludes, could not have composed it when going off to North Africa with D. Sebastião because his expectation must have been that he would return soon and thus could not have expressed such acute pain in his poem (i, 203). It is remarkable the extent to which Faria e Sousa puts himself in the poet's position, inventing a story for the genesis of the sonnet. Cynically, we might say it is all a convenient fiction. More charitably, we can read his comments as an indication of the power of biography as an 'enabling construct in the mind of the reader' and its importance for Faria e Sousa's conception of lyric authorship. ${ }^{43}$ Biography permits both an interpretation of the poem as well as its attribution, even if both are open to being questioned in light of the transmission of the poem in print and manuscript.

Attribution depends on finding what is unique in a writer's use of language. ${ }^{44}$ For Faria e Sousa this was easy as his working assumption was that Camões was the only true poet of his age, so anything of quality must have been his. Nonetheless, the multiplicity of manuscript circulations caused him difficulties, because he needed to assert that poems circulating in manuscripts with various authorial attributions were, in fact, variants of the same text and thus not able to be claimed by different writers. His work as an editor is caught between the dual impulses of expanding Camões's oeuvre and establishing a complete canon of his works and of limiting the proliferation of poems by determining an ur-version of each poem on the basis of multiple poems, which he classes as variants. The terms on which he claims affiliations between texts indicate that he held a notion of originality that looked past 
variations in wording. They were, he consistently says, the product of lack of access to the best copies of a poem, attempts to conceal poetic theft, or the result of endless labor limae. He locates the uniqueness of a poem in its conceit and structure, elements of composition underplayed in accounts of early modern authorship.

In other instances, Faria e Sousa looks to biography to convince readers of his attributions. He goes so far as to imagine the intensity of feelings that individual writers could have felt in different circumstances in their lives that fit with the predicaments described in the poem in question, making judgements about which poet's situation correlated best with the emotions expressed. Throughout these discussions, he emphasizes what is 'propio' to/for a given writer, that is, what is uniquely his or hers. His conception of authorship depended on an indelible bond between a writer's life and their verse. Because poetry, and particularly love lyric, contains what is 'propio' and is figured as a kind of property, attribution is not only a seemingly simple matter of biographical exegesis for Faria e Sousa, but a righting of moral wrongs, the rightful return of stolen goods.

As much as Faria e Sousa criticizes others for making their names on the back of verse written by Camões, he is mostly remembered because Camões has remained the central figure of the Portuguese literary canon. For someone so sensitive to what it meant to say a poem is someone's ('suyo'), his relentless deployment of the first-person possessive pronoun 'mi' [my] in relation to Camões is telling. Camões is more often than not referred to as 'mi Poeta' [my poet] or 'mi P.' for short. Faria e Sousa does not just give things back to Camões, he takes a little something for himself. They might be his poems, Faria e Sousa seems to say, but he is my poet. As much as 'possessive authorship', we need to think about possessive editorship in the early modern period to understand the long history of claiming a text as one's own before the introduction of copyright. ${ }^{45}$

\footnotetext{
${ }^{1}$ Luís Vaz de Camões, Rimas varias de Luis de Camoes, ed. Manuel de Faria e Sousa, i (Lisbon, 1685), 'Prólogo' $§ 19$. Further references to this edition are included in the main text. For the prefatory material, which is not paginated, but is divided into sections in the seventeenth-century
} 
original, I have cited the title of the section and the number of the paragraph, as given by Faria e Sousa.

${ }^{2}$ Hélio J. S. Alves, ‘Sem exclusões: Leituras de poetas portugueses no Siglo de Oro', Limite, 3 (2009), 93-111 (96).

${ }^{3}$ Vítor Aguiar e Silva, 'Cânone das Rimas (O)', in Vítor Aguiar e Silva (org.), Dicionário de Luís de Camões (Alfragide: Caminho, 2011), 228-41 (241). Unless otherwise indicated, all translations are mine.

${ }^{4}$ Vanda Anastácio, 'A criação de um poeta nacional: Breve panorâmica das edições da lírica camoniana entre 1595 e 1870’, Floema, 6.7 (2010), 61-74 (69). Maria Lucília Gonçalves Pires underscores the expansion of the Camonian canon as critical to seventeenth-century editions of his lyric poetry, but deals summarily with the reasons for attribution in her A crítica camoniana no século XVII (Lisbon: Instituto de Culura e Língua Portuguesa, 1982), 46-7, as does Valentín Núñez Rivera, 'Sobre géneros poéticos e historia de la poesía. Los Discursos de Faria e Sousa (de la Fuente de Aganipe a las Rimas de Camoens)', Edad de Oro, 30 (2011), 179-206. On the eclogues, see Edward Glaser, 'La crítica de las eglogas de Garcilaso hecha por Manuel de Faria e Sousa, a la luz de su teoría de la pastoral', in Estudios hispano-portugueses: Relaciones literarias del siglo de oro (Valencia: Castalia, 1957), 3-57, and Thomas R. Hart, 'The Literary Criticism of Manuel de Faria e Sousa', Kentucky Romance Quarterly, 21 (1974), 31-41.

${ }^{5}$ A number of recent studies have explored the prehistory of modern authorship and questions of literary property in the early modern period, revising earlier narratives that suggested the eighteenth century as a major turning point in the emergence of new conceptualizations of authorship, such as Woodmansee and, most influentially, Foucault. Amongst these revisionist studies, see: Kevin Pask, The Emergence of the English Author: Scripting the Life of the Poet in Early Modern England (Cambridge: Cambridge University Press, 1996); Loewenstein, The Author's Due: Printing and the Prehistory of Copyright (Chicago: University of Chicago Press, 2002); Kathy Eden, 'Literary Property and the Question of Style: A Prehistory', in Hall Bjørnstad (ed.), Borrowed Feathers: Plagiarism and the Limits of Imitation in Early Modern Europe (Oslo: Unipub, 2008), 21-38; and 
Geoffrey Turnovsky, The Literary Market: Authorship and Modernity in the Old Regime

(Philadelphia: University of Pennsylvania Press, 2010).

${ }^{6}$ Eden, 'Literary Property', 23.

${ }^{7}$ See Max W. Thomas, 'Eschewing Credit: Heywood, Shakespeare, and Plagiarism before

Copyright', New Literary History, 31 (2000), 277-93 (280) and Turnovsky, The Literary Market, 28-

9.

${ }^{8}$ Hélio J. S. Alves, 'Faria e Sousa, Manuel de', in Aguiar e Silva (org.), Dicionário de Camões, 371-8 (372).

${ }^{9}$ Edward Wilson-Lee, 'Glosses and Oracles: Guiding Readers in Early Modern Europe', in José María Pérez Fernández and Edward Wilson-Lee (eds), Translation and the Book Trade in Early Modern Europe (Cambridge: Cambridge University Press, 2014), 145-63 (149).

${ }^{10}$ See Turnovsky, The Literary Market, 6-7.

${ }^{11}$ See Arthur Marotti, Manuscript, Print, and the English Renaissance Lyric (Ithaca, NY: Cornell University Press, 1995), 135.

${ }^{12}$ See Anastácio, 'A criação', 68-9.

${ }^{13}$ Roger Chartier and Peter Stallybrass, 'What is a book?', in Neil Fraistat and Julia Flanders (eds), Cambridge Companion to Textual Scholarship (Cambridge: Cambridge University Press, 2013), 188204 (195).

${ }^{14}$ See Michel Foucault, 'What is an author?', in David Lodge (ed.), Modern Criticism and Theory: A Reader (London: Longman, 1988), 196-210 (204).

${ }^{15}$ For a deeper discussion of the problem of creating 'complete works,' see Jean Sgard and Catherine Volpilhac-Auger (eds), La Notion d'oeuvres completes, Studies on Voltaire and the Eighteenth Century, 370 (Oxford: Voltaire Foundation, 1999).

${ }^{16}$ Here I draw on the distinction made by Ricks and Goldstein between plagiarism and piracy, see: Christopher Ricks, 'Plagiarism', Proceedings of the British Academy, 97 (1998), 149-168 (156-7, 167-8) and Paul Goldstein, Copyright's Highway: From Gutenberg to the Celestial Jukebox (New York: Hill and Wang, 1994), 12. Two sixteenth-century exceptions to the usual pattern of granting privileges to printers and booksellers would be Gonçalo de Baena and Baltasar Dias, who were both 
granted protection so they could make money from the sale of their books, see Victor Gameiro Drummond, 'Baena e Dias: pioneiros dos privilégios atribuídos aos autores portugueses no século XVI e suas consequências nas novas tecnologias', Revista Brasileira de Direito, 13 (2017), 420-36.

${ }^{17}$ Simon Stern, 'Copyright, Originality, and the Public Domain in Eighteenth-Century England', in Reginald McGinnis (ed.), Originality and Intellectual Property in the French and English Enlightenment (New York: Routledge, 2009), 69-101 (71).

${ }^{18}$ Stern, 'Copyright', 69-70.

${ }^{19}$ Fernando Bouza, Corre manuscrito: Una historia cultural del Siglo de Oro (Madrid: Marcial Pons, 2001), 29.

${ }^{20}$ Luís de Camões, Lusíadas, ed. Manuel de Faria e Sousa (Madrid, 1639), 'Vida del Poeta' col. 48.

${ }^{21}$ Manuel de Faria e Sousa, Fuente de Aganipe o rimas varias [...] Parte Segunda (Lisbon, 1644), fol. $45 \mathrm{r}$.

${ }^{22}$ Manuel de Faria e Sousa, Fuente de Aganipe o rimas varias [...] Parte Quarta (Lisbon, 1644), ‘Prologo' § 14.

${ }^{23}$ This text was only printed long after Faria e Sousa's death in the 1779 edition of Camões's complete works by Tomás de Aquino, but was alluded to in the 1589 volume of the Rimas Várias. I was not able to consult the 1779 edition, but the Visconde de Juromenha cites Faria e Sousa's criticisms in his nineteenth-century edition: Luís de Camões, Obras de Luiz de Camões, ed. Visconde de Juromenha, 6 vols (Lisbon: Imprensa Nacional, 1860-1869), iii (1861), 341.

${ }^{24}$ See Simon Park, 'Diogo Bernardes's Brandura', MLQ, 78 (2017), 465-89.

${ }^{25}$ Mark Rose, Authors and Owners: The Invention of Copyright (Cambridge, MA: Harvard University Press, 1993), 3.

${ }^{26}$ For a searching discussion of the authorship of this poem, see Alves, 'Sem exclusões', 101-4.

${ }^{27}$ Paul Zumthor, Essai de poétique médiévale, rev. ed. (1972; rev. ed. Paris: Seuil, 2000), 84.

${ }^{28}$ Vanda Anastácio, Visões da Glória: Uma introdução à poesia de Pêro de Andrade Caminha, 2 vols (Lisbon: Fundação Calouste Gulbenkian/Junta Nacional de Investigação Científica e Tecnológica, 1998), ii, 670.

${ }^{29}$ Thomas M. Greene, The Light in Troy (New Haven: Yale University Press, 1982), 39. 
${ }^{30}$ Hall Bjørnstad, 'Introduction', in Bjørnstad (ed.), Borrowed Feathers, 5-17 (6).

${ }^{31}$ For instances of where this narrative is reproduced, see, e.g. Andrew Bennett, The Author (London: Routledge, 2005), 50-4; Roger Chartier, The Order of Books, trans. Lydia G. Cochrane (Stanford: Stanford University Press, 1994), 29-37; Rose, Authors and Owners, 1-5; and Martha Woodmansee, 'The Genius and the Copyright: Economic and Legal Conditions of the Emergence of the "Author"', Eighteenth-Century Studies, 17 (1984), 425-48.

${ }^{32}$ Eden, 'Literary Property', 23.

${ }^{33}$ Woodmansee, 'The Genius and the Copyright', 445.

${ }^{34}$ Luís Vaz de Camões, Rimas de Luis de Camoens segunda parte (Lisbon, 1616), fol. 23v.

${ }^{35}$ Camões, Segunda parte, fol 24r.

${ }^{36}$ See Rose, Authors and Owners, 35, 131-2, for eighteenth-century debates on whether ideas could be considered property.

${ }^{37}$ See, for instance, Diogo Bernardes's reminder to Pêro de Andrade Caminha that poems must be worked and reworked, and António Ferreira's summary of Horatian ideas in a verse letter to Bernardes in Diogo Bernardes, O Lima, ed. J. Cândido Martins (Braga: Caixotim, 2009), 279, 293. ${ }^{38}$ Thomas, 'Eschewing Credit', 278, indicates how eschewal was as important for early modern writers as claims to authorial ownership, citing, for instance, the example of Petrarch who says he would rather be robbed of poems than see his name associated with those of a perceived lower quality, which he never wrote.

${ }^{39}$ Sebastián de Covarrubias Horozco, Tesoro de la lengua castellana, o española (Madrid, 1611), fol. $597 \mathrm{v}$.

${ }^{40}$ Eden, 'Literary Property', 31-2.

${ }^{41}$ Foucault, 'What is an Author?', 204-5.

${ }^{42}$ Juan Luis Vives, On Education: A Translation of the De trandendis disciplinis of Juan Luis Vives, trans. Foster Watson (Cambridge: Cambridge Universtiy Press, 1913) 303-4.

${ }^{43}$ Ann Jefferson, Biography and the Question of Literature in France (Oxford: Oxford University Press, 2007), 21. 
${ }^{44}$ Harold Love, Attributing Authorship: An Introduction (Cambridge: Cambridge University Press, 2002), 4.

${ }^{45}$ The phrase 'possessive authorship' comes from the title of Joseph Loewenstein, Ben Jonson and Possessive Authorship (Cambridge: Cambridge University Press, 2002). 